\title{
The impact of social media on managing the image of the Polish national football
} team

\footnotetext{
Authors' contribution:

A) conception and design of the study

B) acquisition of data

C) analysis and interpretation of data

D) manuscript preparation

E) obtaining funding
}

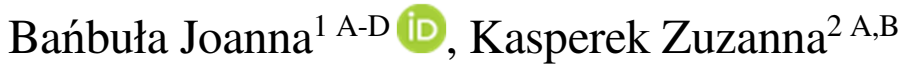 \\ ${ }^{1}$ Józef Pitsudski University of Physical Education in Warsaw, Poland \\ ${ }^{2}$ Polish National Television, Warsaw, Poland
}

ABSTRACT

Presented paper contains looks which mainly attempt to analyse the promotion in sport by social media and brand image management on the example of „Connected by football" channel.

Research process required usage of diagnostic survey method. Exploration shows that social media has contributed to popularisation and improved the image of the Polish National Football Team. Respondents' opinions about the formula of the „Connected by football" channel. The reasons and motives for the interest of the „Connected by football" channel are mainly involved with sports activities and the team's life outside of trainings and matches. Survey shows that half of the respondents changed their mind about the players after watching the video materials and due to this fact the emotional bond between players and supporters increase. The research presents that „Connected by football” channel played a significant role in Polish National Football Team image's building.

KEYWORDS social media, sports marketing, image, sports brand, public relations, football

\section{Introduction}

Professionalization, commercialization and globalization of sport disciplines led to the creation of a sports market. Progressive development has created a strong competition therefore building strong sports brand has become a tool of the fight against competition on the market. Nowadays, in the aspect of management the sports market takes an example from enterprises to effectively operate in the environment. This process includes also communication with clients. Social media, which have evolved into huge information bases and a place for discussion, has become communication channel between organizations and fans (Hudson et al., 2016).

The aim of this paper is finding the answer if the use of social media as a tool for promoting the Polish National Football Team improved the team's image? Did the activities related to the use of social media as a tool for promoting the Polish National Football Team increased the fans' sympathy for athletes? And finally does the popularity of the „Connected by football” channel depend on the successes of the Polish National Football Team? Why did PZPN decide to use social media in image management? 
Based on research questions following research hypotheses have been formulated:

1. The use of social media to promote the Polish National Football Team has helped fans get to know the players better.

2. PZPN uses social media to manage its image in order to attract young people to support Polish National Football Team.

3. The use of social media has significantly improved the image of the brand - Polish National Football Team.

4. The sports successes of the Polish National Football Team helped to popularize the channel „Connects us football”

A sports brand can be built by many entities: sports organization, sporting event, sports equipment manufacturer or sportsmen themselves. Currently, a particularly strong cult of sports personalities contributes to the tremendous strength of competitors' brands in the business market (Ratten, 2010). Companies willingly use them for marketing activities through sport. Sporting successes evoke strong emotions among consumers, the feeling of pride and joy of winning can be transferred to a product or service whose ambassador is a given sports personality or a team (Ratten \& Ratten, 2011). According to the definition of the American Marketing Association, the brand is defined as a „name, design, symbol or any other feature that identifies a product or service of a given seller in contrast to other products and services of other sellers" (Stern, 2006). Shaun Smith and Joe Wheeler (2002) understand a brand as a trademark that distinguishes products from one supplier from another. Allen P. Adamson (2006) emphasizes that the brand is a promise that reaches the consumer's mind. It has an amazing strength binding it with a specific product or service, causing an emotional reaction - negative or positive. Keller (2008, p. 2) submits that ,a brand is something that has actually created a certain amount of awareness, reputation, prominence, and so on in the market place". Zawartka (2013) claims that a sports brand should correspond to the emotions experienced by the consumer in contact with sport and the values that the sports spectacle brings with it. The emotional potential of can be flexibly extended to other brands and even industries.

Bykowski (2007) emphasizes that the Polish National Football Team sport brand is created by consequent entities:

- National team coach.

- Players, some of them became stars of the team often attracting fans with their personality or sports skills. The image of the team is influenced not only by their attitude during the match and the quality of the game, but also by their private attitude and statements in the media.

- Supporters whose behavior during meetings at the national level may build the image of a country.

- Polish Football Association (PZPN).

- A league system in which games are organized.

- Sponsors.

- Historical experience related to referring to previous successes or failures.

Kropielnicki (2008) notes that the status of a sports brand wants to have not only unions and sports clubs, but also leagues, events, objects or producers. Shaping the brand image is a strategic process. Due to the fact that all circumstances may affect the perception of sports brand consumers'. Shank (2004) emphasizes that a strong sports brand is closely identified with the sports environment in which it operates. However, before it exists, it will consolidate its position on the sports market and attach to itself the consumer, it must be created. The process of creating takes place in the following stages: brand awareness, the image of the brand, brand value and loyalty to the brand. Brand awareness is connected with its recognition and remembrance by the consumers. Developing a high level of brand awareness is the basis for building its image in the environment in which it operates. The image of the brand is a group of beliefs, ideas and opinions about it. This is 
evidenced by features such as: name, price, promotion, distribution method, quality, packaging, service package and benefits provided to the recipients in terms of satisfying individually specified need.

Commercialization of sport has made the concept of a sports brand more and more present in the literature. Subsequent authors began to notice and identify brands operating only or also in the field of sport. Kotler (2016) claims that the aforementioned features constitute the brand's identity, understanding it as a compilation of information and images that make up a sports product. Current trend of extending or modifying the meanings of business concepts also refers to the definition of the concept of sports brand. Arai et al. (2014) emphasize the importance of using the model of athlete brand image (MABI) which identified the critical brand associations for athlete brand in developing brand equity among consumers. MABI consists three dimensions: athletic expertise, attractive appearance, and marketable lifestyle.

Shaping the brand image is a long and strategic process, requires a broad knowledge of the image, tools and sense in social relations. It should be remembered that the „brand” itself is only a showcase of products and services, which should be disseminated through the promotion in the media.

\section{Public Relations as a tool to build a sports brand}

Public relations shapes various forms of relations between enterprises and the environment and tries to maintain these relationships. Kotler and Keller (2016) emphasize that public relations includes various programs that aim to promote or protect the company's image and its individual products. Public relations are mainly defined as a management function that enables enterprises to acquire positive relations with consumers. Public relations is understood as multilateral contacts and relations of the organization with the external and internal environment as well as all activities aimed at evoking or maintaining interest in its work, and - creating a positive attitude and public trust in the association (L'Etang, 2006). Public relations activities are directly related to creating a positive image of the organization, creating good relations between the organization and the environment, and seeking favorable opinions of the media, which do not spread any harmful messages about the organization (Sznajder, 2015).

The main components of PR in sport are: media relations (MR) and community relations. The first is a strategy of cooperation with the media, and the other is the activity of the company directed to the environment (L'Etang, 2008). These activities build a community of sympathizers and supporters referred to as a fan base building. Qualman (2013) emphasizes that more and more of these activities are being transferred to the Internet. The main advantage of the Network is an easier access to published content, both for consumers and journalists. The cost-effective distribution is also a convincing aspect. In the literature on the subject, the concept of ,online public relations” began to appear, which can be understood as activities activating recipients (Woźniakowski, 2016). Internet public relations is a function of management, through the Internet network tools, of a continuous and planned nature, enabling communication between the organization and its external and internal environment. The activities include: social networks, websites, newsletters, video conferences, chats, internet forums, online stores, blogs, microblogs, mobile services and instant messengers. The implementation of these activities should be based on a coherent PR strategy so that everything is planned, continuous and conscious (Popp \& Woratschek, 2015). 


\section{Social media in marketing communication}

Communication in virtual space is an extremely important area in conducting marketing communication. These days, we are dealing with so-called network communications, which is based on the exchange of data and information via a computer network (Filo et al., 2015). The factor generating the emergence of marketing innovations is primarily the development of information technology and the skillful identification of consumer needs. Both elements influence the implementation of new methods in the field of services and changes in the marketing communication process (Katz \& Heere, 2015). Nowadays social media takes a dominat place in social network communication (Jahn \& Kunz, 2012).

Despite the growing popularity of social media, in the literature of the subject, it is not easy to find their nonsuperficial definition. Social media has been defined by Andras Kaplan and Michael Haenlein (2010, p. 61) as ,,a group of Internet-based applications that build the ideological and technological foundations of Web 2.0, which allows users to create and exchange content created by users". All technological solutions that lead to interaction between their users are defined as Web 2.0. The foundation of social media and Web 2.0 are Internet communities made up of users who ,produce” content. Social media platforms have occured as a dominant digital communication channel via which consumers learn about, share information on, and have a possibility to interact with brands (Laroche, 2013). All ,the tools, platforms, and applications that enable consumers to connect, communicate, and collaborate with others" are understood as social media (Williams \& Chinn, 2010, p. 422).

The main differences between social media and their traditional counterparts. The user of traditional media only served as the recipient, in case of social media he directly participates in creating their content. The dissimilarity of social media is based on consumer's experience realized through conversations. The essence of communication was a conversation and discussion, and not as in traditional media - information. This shows how important it is for marketers to identify the needs and behavior of consumers. The use of social media by sports enterprises can build a tripartite relationship involving business partners, consumers and nongovernmental organizations. Social media can fulfill a number of functions as: co-participation, co-creation, building and maintaining relationships, communication, current information and publication (Kaznowski, 2013). Nowadays brands use social media strategically to establish relationships with environment and facilitate outcomes (Filo et al., 2015).

\section{Methods}

The aim of this work is to characterize the promotion in sport through social media and brand image management on the example of the „Connected by football” channel on YouTube. The study analyzed the use of social media, as a tool for managing the brand image of the Polish National Football Team, and assessed the activities of the „Connected by football” channel.

The research process requires use of following methods: diagnostic survey and interview text analysis. The first method involves questionnaire survey. Respondents had the opportunity to fill them through the Internet. Survey created for the purposes of obtaining answers to the research questions and contained 25 questions. 17 were directly related to the research problem and 8 described socio-demographic profile of respondents. The questionnaire contains detailed questions regarding the motives of watching, evaluation and popularity „Connected by football” channel among Polish National Football fans. Participation in the research was voluntary and anonymous. The research was carried out on a group of 100 people, in 2018. Survey was created on a special portal where respondents had the opportunity to fill them through the Internet. From the group of 100 people, $78 \mathrm{knew}$ „Connected by football” channel. 


\section{Research material}

The selection of the team was directly related to its promotional activities in the social media. The Polish National Football Team is a football team that represents the Republic of Poland in international matches and tournaments. National Team is appointed by the manager, and can only be determined by players with Polish citizenship. The Polish Football Association (Polski Związek Piłki Nożnej PZPN) is responsible for its functioning (Gowarzewski, 2017). Funding of the National Team is handled by PZPN, which receives a significant amount of money from sponsors, sales of marketing rights and ministerial sources. National Team also earns through sports broadcasts, sale of copyright, tickets, merchandising etc. As noted by Gowarzewski (2017) efficient management of the team of Poland rests on the shoulders of the president of PZPN. Since 2012, the position has been held by Zbigniew Boniek, a former outstanding football player of Polish National Football Team, later a coach, sports activist and a businessman. The image of the association improved after taking over the office of the President by Zbigniew Boniek. PZPN also regained its transparency and fans'confidence. The team began to achieve satisfactory results; qualified for the Euro 2016 and reached the quarterfinals of this tournament. Thus achieving the best result at the European Championships in history.

The strategy of comprehensive reconstruction of the image of the National Team also assumed the use of social media. The process of rebuilding the media image of football in Poland began in December 2012, when Janusz Basałaj became the communication director of PZPN. President Zbigniew Boniek came up with the idea of creating the substitute of federal television. The aim of the project was to create a YouTube channel showing behind the scenes of Polish football. Project also contain content related to other representations: youth, women, beach soccer, futsal and so on. Initially, reportage style films were made. In order to change the format of the shots, technological changes were made involving the use of GoPro cameras, which did not restrict the players and allowed them to enter a free and natural reaction with the camera at any time.

The PZPN run the Internet website named „Connected by football”. One of its tool was YouTube channel. The main concept was showing the fans the backstage of National Team which presents football to fans in an interesting and innovative way. „Connected by football” channel presents reports, match abbreviations, trainings, interviews, press conferences and a series of materials titled „Expert Studio”. The media face of the YouTube channel is Łukasz Wiśniowski, a journalist who accompanies the first National Team during sparring matches, tournaments and games. Channel journalists began working during the elimination to the European Championships. The relations between journalists and footballers became more intimate, and thanks to that the materials recorded on the channel gained credibility. The first success of „Connected by football” was noticed during the Euro 2016 Championships, when there were as many as 2 million unique users. Currently, the YouTube channel has over 400,000 subscribers.

\section{Characteristics of respondents}

The survey questionnaire was sent via Internet to 100 people, 78 of whom knew "Connected by football" channel, and 22 did not. In the study, a group of 78 subjects was taken into account, assuming as $100 \%$. The data shows men were the more numerous $71 \%$ (55 people) and women constitute $29 \%$ ( 23 people). The stereotype confirms that men are still more interested in football and players' lives. Analyzing the structure of the respondents in terms of age, it turns out that $76 \%$ (59 people) of the examined persons are in the 19-26 age range. The second group (19\%, 1 person) consist of respondents aged 27-36, then 3\% (2 people) group of respondents aged 37-54. The lowest number of respondents is between $0-18$ and $2 \%$ ( 2 people). The study do not involve people over 55 years. The study shows that young people represents the group which is easiest to attract through social media. 
Most of the respondents (53\%, 41 people) are living in cities over 500,000. residents. In cities with 100-500 inhabitants live $15 \%$ (12) of respondents and city residents up to 100,000, there are $19 \%$ of them (15 people). 13\% (10 people) live in the countryside. The largest group 35\% (27 people) are people earning PLN 1,500 a month. The respondents earning income between PLN 1501-2500 per month is $23 \%$ (18 people). The study also included people earning 2501-3500 zlotys per month - 20\% (16 people). The lowest number of respondents indicate their income in the ranges of 3501-4500 PLN and 4500 PLN which in turn were 12\% (9 people) and $10 \%$ (8 people).

"Connected by football” is observed mainly by young men. The study group comes mainly in large cities, which may be associated with a greater possibility of access to the Internet. The degree of earnings in most respondents does not exceed PLN 2,500, which may indicate that they are in the early stages of entering the labor market or are students.

\section{Findings}

\section{Reasons and motives for interest in „Connected by football” channel}

The main reason for starting following materials on the channel is the opportunity to see backstage of Polish National Football Team. This response is obtained by as much as $85 \%$ (66 people). Equally highly evaluate reasons are presenting the life of Polish National Football Team apart from trainings and matches (83\%, 64 people), interest in football by the respondents $(79 \%, 61$ people), and presenting curiosities about Polish National Football Team $(70 \%, 55$ people). Another reason is satisfaction with the style of recording materials, which receive $68 \%$ (53 people) of positive ratings. Viewers admit that sports results achieved by Polish National Football Team contribute to watching the channel „Connected by football” (56\%, 44 people). Comparable are the results of showing youth teams (32\%, 25 people) and the popularity of the channel among family and friends $(29 \%, 22$ people). The least inviting aspect to watch channel is a shortcut magazine for 2 leagues $(18 \%, 14$ people). These results seem to translate into the goals set by PZPN activists and the creators of the channel. Łukasz Wiśniowski explained that the main goal for his work in „Connected by football” is to promote football. That is why they aimed to show backstage of National Team.

Respondents evaluate the channel on scale from 5 to 1, were 5 is the highest grade and 1 the lowest. 51\% (40 people) of the respondents review the channel for a highest grade. The good rating (4) choose of $41 \%$ ( 32 people). The current formula of the channel has been rated very well, it may be related to the inability to compare the channel „Connected by football” with a similar format.

\section{Moment of increase popularity of „Connected by football” channel}

UEFA Euro 2016 Qualifying were decisive development moment for „Connected by football” channel. Examination shows that $53 \%$ start following the channel during qualifying tournament. The next most frequently chosen moments were UEFA Euro 2016 (15\%), in which the Polish National Team reached the quarter-finals. 14\% (11) of the respondents declared to start watching the channel since UEFA Euro 2012 held in Poland and Ukraine. Only 12\% follow channel since the beginning. Popularity of the channel is related to the sporting successes achieved by the national team ${ }^{1}$.

\footnotetext{
${ }^{1}$ Before UEFA EURO 2008 Polish National Football Team did not qualify to UEFA EURO tournament. In 2012 were co-hosted this event with Ukraine.
} 


\section{The influence of the "Connected by football" channel on the athletes-supporters relationship}

Respondents were asked whether the channel "Connected by football" influenced the promotion of Polish National Football Team, 82\% (64) of people respond positively, and only $8 \%$ (6 people) claim that the channel do not affect the promotion of the team. The collected data shows that „Connected by football” channel undoubtedly helped in the promotion of the National Team, this assessment is certainly related to the direct feelings of the respondents. They experience in their environment and the media more publicity about Polish Football Association and Polish National Football Team. One of the aims of this research was to examine the opinions if "Connected by football" influences the strengthening of the emotional bond between the fans and Polish National Football Team. After watching this channel 58\% (45 persons) of people declare an increase in intimacy with the team, and just under 18\% (14 persons) are against it.

The $82 \%$ of respondents ( 64 people) claim that the „Connected by football” run by the Polish Football Association on YouTube influenced the improvement of the image of Polish National Football Team. Only $7 \%$ (5 people) of people participating in the study present a different opinion. The results show how much the channel helped to improve the image of the Polish National Football Team. Study shows that half of the respondents (50\%, 39 people) after watching the materials published on the channel „Connected by football” changed their minds about the players. Less than $21 \%$ (16 people) do not. On the other hand, $29 \%$ (23 people) from the studied group are unable to determine whether something has changed after reading the content presented on the channel. Łukasz Wiśniowski accompanies the players for most of the time on sports meetings. Due to this fact fans can watch players in different situations. Materials presented on the channel helped fans to learn about the characters of individual players, which leads to a change of opinion on them. Examination shows that using social media for the promotion of Polish National Football Team has an impact on the better recognition of the players by the fans.

Conducted research has shown that the viewers of the channel "Connected by football” have strongly strengthened the ties with National Team. Data shows their positive impact in building image and promotion of football in Poland. According to the research group, the use of social media to improve the image of the brand of the team was a very good move. The rapid implementation of consumer needs makes the channel the best way to promote and create National Team brand.

\section{Conclusion}

Social media plays an important role in managing the image of a sports brand. Consequently, fans have the opportunity to get to know the competitors better, which increases their attachment to the team. This helps to improve the brand image. Commercialization of sport has caused Polish National Football Team to become a brand that triggers many positive emotions, so it is necessary to constantly take care of its reputation and image. The real change in quality in managing the image of a sports brand is the activity of Polish Football Association on YouTube. By creating Connected by football" channel, they created a possibility of constant interaction with the fans. Subscription of the channel helps fans to receive information about new materials, which affects their attachment to the national team and sports products that it offers.

Most of the respondents declared an increased emotional connection with Polish National Football Team after watching the materials on the channel. The majority of supporters confirmed the significant impact of the materials on the "Connected by football” channel on the Polish football promotion. Hypothesis that the use of social media has significantly improved the image of the brand Polish National Football Team can be confirmed.

Respondents indicated that backstage from Polish National Football Team sparings and interviews with players are most wanted to watch film materials on „Connected by football” channel. Half of the surveyed 
fans changed their minds about the players after watching materials. This facts confirm the hypothesis the use of social media to promote the Polish National Football Team has helped fans get to know the players better.

UEFA Euro 2016 Qualifying and UEFA Euro 2016 where Polish National Team reached the quarter-finals, were a developing moment for „Connected by football” channel. Hypothesis that the successes of the Polish National Football Team helped to popularize „Connected by football” channel is confirmed. Sports success turned out to be a stimulus for further work on changing the current perception of the National Team by fans.

Research shows that „Connected by football” is observed mainly by young men. Hypothesis about used social media to manage its image in order to attract young people to support Polish National Football Team is confirmed.

The authors of the work managed to achieve the goal set at the beginning and confirmed the working hypothesis. The results of the research showed that supporters are showing interest in the life of the National Team, not only during matches, but also outside of them. „Connected by football” channel fulfilled its basic assumptions, which were bringing players closer to the fans and popularizing football. The authors learned the viewers' motives to watch the materials presented by the channel, knows what they like the most and what is most important to them as supporters. Creation of the „Connected by football” channel by Polish Football Association has built up a positive relationship between supporters and players. Social media are a tool of learning the needs and expectations of fans, this helps to prepare a personalized offer for them.

Positive image attracts fans and it might be translate to future financial revenues. Consumers who are satisfied with the brand on social media are definitely more likely to buy products related to this team. Polish National Football Team is a brand whose image depends on the players and people directly cooperating with it. The dedication to brand management to specialists who decided to use social media turned out to be a good move, and the Polish Football Association became a pioneer among global football associations and is a role model by UEFA. It is worth following the further actions of the Polish Football Association in the social media.

Using social media in building a sports brand is a very interesting topic to explore, still fresh and not fully discovered by marketing departments in sports organizations. Similar research carried out in other sports would help the sports organization to build appropriate marketing strategies. Competition on the sports market requires the intensification of marketing activities and the usage of new tools to strengthen ties on the line of a sports organization - a fan who is a consumer of a sports product. Therefore, sports organizations should constantly improve their activities and base them on the latest trends in the field of marketing. Currently, we are entering the era of Marketing 4.0, which combines online and offline interaction between the organization and its recipients (Kotler et al. 2017). Its aim is to stimulate consumer brand advocacy.

\section{REFERENCES}

Adamson, A. P. (2006). Brand simple. Palgrave MacMillan.

Arai, A., Ko, Y. J., \& Ross, S. (2014). Branding athletes: Exploration and conceptualization of athlete brand image. Sport Management Review, 17(2), 97-106. DOI: https://doi.org/10.1016/j.smr.2013.04.003

Bykowski, S. (2007). Analiza medialna marki na przykładzie piłkarskiej reprezentacji Polski /Media analysis of the brand on the example of Polish National Football Team/. In H. Mruk (Ed.), Marketingowe zarzadzanie sportem Marketing sport management/. Poznań: Sport \& Business Foundation.

Filo, K., Lock, D., \& Karg, A. (2015). Sport and social media research: A review. Sport Management Review, 18(2), 166-181. DOI: https://doi.org/10.1016/j.smr.2014.11.001

Hudson, S., Huang, L., Roth, M. S., \& Madden, T. J. (2016). The influence of social media interactions on consumerbrand relationships: A three-country study of brand perceptions and marketing behaviors. International Journal of Research in Marketing, 33(1), 27-41. DOI: https://doi.org/10.1016/j.ijresmar.2015.06.004. 
Jahn, B., \& Kunz, W. (2012). How to transform consumers into fans of your brand. Journal of Service Management, 23(3), 344-361. DOI: https://doi.org/10.1108/09564231211248444.

Kaplan, A. M., \& Haenlein, M. (2010). Users of the world, unite! The challenges and opportunities of Social Media. Business Horizons, 53(1), 59-68. DOI: https://doi.org/10.1016/j.bushor.2009.09.003.

Katz, M., \& Heere, B. (2015). Empowerment within brand communities: Overcoming the Achilles' Heel of scale-free networks. Sport Management Review, 18(3), 370-383. DOI: https://doi.org/10.1016/j.smr.2014.10.001.

Kaznowski, D. (2013). Social media - społeczny wymiar Internetu /Social media - the social dimension of the Internet/. In J. Królewski \& P. Sala (Eds.), E-marketing (81-103). Warszawa: Wyd. Naukowe PWN.

Keller, K. (2008). Strategic brand management: Building, measuring and managing brand equity. Upper Saddle River, NJ: Prentice Hall

Kotler, P., \& Keller, K. L. (2016). Marketing. Poznań: Wyd. Rebis,.

Kotler, P., Hermawan, K. \& Setiawan, I. (2017). Marketing 4.0. Warsaw: MT Biznes.

Kropielnicki, K. (2008). Rynek sportowy a marka /The sports market and the brand/. In H. Mruk, M. Chłodnicki (Eds.), Kreowanie marki w sporcie /Creating a brand in sport/. Poznań: Sport \& Business Foundation.

L'Etang, J. (2006). Public relations and sport in promotional culture. Public Relations Review, 32(4), 386-394. DOI: https://doi.org/10.1016/j.pubrev.2006.09.006

L'Etang, J., \& Hopwood, M. (2008). Sports public relations, Public Relations Review, 34(2), 87-89.

Laroche, M., Habibi, M. R., \& Richard, M. O. (2013). To be or not to be in social media: How brand loyalty is affected by social media?. International Journal of Information Management, 33(1), 76-82.

Popp, B., \& Woratschek, H. (2016). Introducing branded communities in sport for building strong brand relations in social media. Sport Management Review, 19(2), 183-197. DOI: https://doi.org/10.1016/j.smr.2015.06.001.

Qualman, E. (2013). Socialnomics: How social media transforms the way we live and do business. Hoboken, New Jersey: John Wiley \& Sons.

Ratten, V. (2010). Sport-based entrepreneurship: towards a new theory of entrepreneurship and sport management. International Entrepreneurship and Management Journal, 7(1), 57-69. DOI: https://doi.org/10.1007/s11365-010-0138-z.

Ratten, V., \& Ratten, H. (2011). International sport marketing: practical and future research implications. Journal of Business \& Industrial Marketing, 26(8), 614-620. DOI: https://doi.org/10.1108/08858621111179886

Shank, M. D. (2004). Sports marketing. A strategic perspective. Wyd. Prentice-Hall, New Jersey 2004, s. 268.

Smith, S., \& Wheeler J. (2002). Managing the customer experience. Pearson Education.

Stern, B. B. (2006). What Does Brand Mean? Historical-Analysis Method and Construct Definition. Journal of the Academy of Marketing Science, 34(2), 216-223. DOI: https://doi.org/10.1177/0092070305284991.

Sznajder, A. (2015). Marketing sportu /Marketing of sport/. Warszawa: Wyd. PWE.

Sznajder, A. (2017). Sport jako biznes w czasach globalizacji /Sport as business in the times of globalization/. Warszawa: Wyd. Polskie Wydawnictwo Ekonomiczne.

Williams, J., \& Chinn, S. J. (2010). Meeting Relationship-Marketing Goals through Social Media: A Conceptual Model for Sport Marketers. International Journal of Sport Communication, 3(4), $422-437 . \quad$ DOI: https://doi.org/:10.1123/ijsc.3.4.422.

Woźniakowski, M. (2016). Narzędzia internetowego public relations wykorzystywane przez kluby piłkarskiej Ekstraklasy w komunikacji /Online public relations tools used by Ekstraklasa football clubs in communication/. Handel Wewnętrzny, 6, 332-344.

Zawartka, M. (2013). Znaczenie marki klubu sportowego /The Importance of the sports club brand/. Zbornik recenzowanych prispevkov, Marketing manazment, obchod a socjalne aspekty podnikania, Kosice. 


\section{AUTHOR'S ADDRESS:}

Joanna Bańbuła

Józef Piłsudski University of Physical Education in Warsaw

Faculty of Physical Education

Marymoncka 34

00-968 Warsaw

Poland

Email: joanna.banbula@awf.edu.pl

Received: 29 June 2019; Accepted: 20 May 2020 